\title{
Effects of increased content of organic selenium in feed on the selenium content and fatty acid profile in broiler breast muscle
}

\author{
Zlata Kralik ${ }^{1}$, Gordana Kralik ${ }^{1}$, Manuela Grčević ${ }^{1}$, Pavel Suchý², Eva Straková2 \\ ${ }^{1}$ Department of Special Zootechnics, Faculty of Agriculture J.J. Strossmayer University of Osijek, Croatia \\ ${ }^{2}$ Department of Nutrition, Animal Husbandry and Animal Hygiene, \\ Faculty of Veterinary Hygiene and Ecology, University of Veterinary and Pharmaceutical Science Brno, \\ Czech Republic
}

Received July 14, 2011

Accepted February 14, 2012

\begin{abstract}
The aim of this study was to determine the effects of organic selenium supplemented to broiler feed on the selenium content and fatty acid profile in broiler breast muscle tissue. The study was carried out on 60 male Ross 308 broilers that were slaughtered at the age of 42 days. After day 21 , the broilers were divided into three experimental groups (P1, P2, P3), and each group was given separately prepared finisher diets that contained $18 \%$ of crude protein and 14.67 $\mathrm{MJ} / \mathrm{kg} \mathrm{ME}$ (finisher diet contained $6 \%$ of oil, of which 3\% was sunflower oil, and 3\% was linseed oil added for the purpose to increase portion of $\alpha$-linolenic fatty acid. The content of organic selenium (Sel-Plex ${ }^{\circledR}$ ) supplemented in the finisher diet was as follows: no selenium, $0.3 \mathrm{mg}$ $\mathrm{Se} / \mathrm{kg}$ of feed and $0.5 \mathrm{mg} \mathrm{Se} / \mathrm{kg}$ of feed for P1, P2 and P3 group, respectively. It was determined that the group P3 had a significantly higher $(P<0.05)$ content of selenium in breast muscle $(0.256 \mathrm{mg} \mathrm{Se} / \mathrm{kg}$ of tissue) than group P2 $(0.183 \mathrm{mg} \mathrm{Se} / \mathrm{kg}$ of tissue $)$ and P1 $(0.087 \mathrm{mg} \mathrm{Se} / \mathrm{kg}$ of tissue). Supplementation of selenium to feed at the amount of $0.3 \mathrm{mg} / \mathrm{kg}$ affected the fatty acid profile in breast muscle tissue by increasing portions of $\alpha$-linolenic, eicosapentaenoic, docosapentaenoic and docosahexaenoic acids and total $\mathrm{n} 3$ polyunsaturated fatty acids, and by lowering portion of total saturated and monounsaturated fatty acids.
\end{abstract}

Nutrition, poultry, composition, sunflower oil, linseed oil

Poultry production in Croatia has a long tradition. In 2008, yearly consumption of fresh meat was $44.68 \mathrm{~kg}$ per household member. The most consumed meat was poultry $(16.96 \mathrm{~kg})$, followed by pork $(15.51 \mathrm{~kg})$, beef $(9.05 \mathrm{~kg})$; meat of other animals was less consumed. Popularity of poultry meat can be justified by the fact that it is of satisfactory nutritive quality, not expensive and meets organoleptic demands of consumers. Grains are the basic forage of broiler feed, and additional fats, mostly sunflower oil rich in n-6 polyunsaturated fatty acids (PUFA) is added to broiler feed for the purpose of metabolic energy (ME) balancing. Grains produced in Croatia are low in selenium content; therefore it is important to supplement this microelement to broiler feed. The aim of this study was to investigate the effects of increased selenium content in broiler feed (containing 3\% of linseed oil and $3 \%$ of sunflower oil) on selenium content and fatty acid profile in broiler muscle tissue.

\section{Materials and Methods}

The research was carried out on 60 male broiler hybrids of the Ross 308 . From the $1^{\text {st }}$ to $21^{\text {st }}$ day the broilers were fed a starter diet balanced at $22 \%$ crude protein and $13.90 \mathrm{MJ} / \mathrm{kg} \mathrm{ME}$. After day 21 , the broilers were divided into three groups (P1, P2 and P3) and fed finisher diets containing linseed oil (3\%) and sunflower oil $(3 \%)$, and differing in the amounts of organic selenium (Sel-Plex ${ }^{\mathbb{R}}$, Alltech) added in groups P2 and P3 (0.3 mg $\mathrm{Se} / \mathrm{kg}$ of feed and $0.5 \mathrm{mg} \mathrm{Se} / \mathrm{kg}$ of feed, respectively); diet given to group P1 was not supplemented by selenium. Chemical analysis of diets provided data on selenium content. The diet of P1 group contained $0.0822 \mathrm{mg}$ $\mathrm{Se} / \mathrm{kg}$, P2 diet contained $0.2840 \mathrm{mg} \mathrm{Se} / \mathrm{kg}$, and P3 diet had $0.4380 \mathrm{mg} \mathrm{Se} / \mathrm{kg}$. Prior to supplementing selenium, 
feed was analyzed for its content of fatty acids, as follows: $22.67 \%$ of total saturated fatty acids, $25.48 \%$ of total monounsaturated fatty acids, $39.76 \%$ of total n-6 polyunsaturated fatty acids, $6.51 \% \alpha$-linolenic fatty acid and $6.51 \%$ of total $n-3$ polyunsaturated fatty acids.

Finisher diet contained $18 \%$ crude protein and $14.67 \mathrm{MJ} / \mathrm{kg} \mathrm{ME}$. The method with ICP Optical Emission Spectrometry was applied to analyze content of selenium in diets and in broiler muscle tissue (Davidowski 1993). Fatty acid profile in diets and in breast muscle lipids was determined by Chrompack CP-9000 chromatograph equipped with flame ionization detector (Csapo et al. 1986). Lipid oxidation in breast muscles was determined by the method of Ohkawa et al. (1979), absorbance of samples was read at $532 \mathrm{~nm}$ on the Varian Cary 50 Conc UV-Visible spectrophotometer, and the Thiobarbituric Acid Reactive Substances (TBARS) values were calculated according to standard curve made by 1,1,3,3-Tetramethoxypropane (TMP) and presented in nmol of malonaldehyde (MDA) per gram of tissue. Effects of feed-supplemented selenium on the selenium content and fatty acid profile in broilers breast muscle tissue was evaluated by One-way ANOVA. Differences between groups were determined by Fisher's LSD test, and processed by Statistica for Windows v 7.0 (Statsoft Inc., 2004).

\section{Results}

As diets were mixed on the basis of increased selenium content, it was expected that contents of selenium in breast muscles among examined broiler groups would significantly differ. The highest content of selenium was determined in breast muscle tissue of group P3 (0.256 $\mathrm{mg} \mathrm{Se} / \mathrm{kg}$ of tissue).

Breast muscle tissue in groups P2 and P1 contained $0.183 \mathrm{mg} \mathrm{Se} / \mathrm{kg}$ and $0.087 \mathrm{mg}$ $\mathrm{Se} / \mathrm{kg}$ of tissue $(P<0.05)$, respectively. Table 1 presents an overview of fatty acid content in breast muscle lipids calculated in \% of total fatty acids. The content of selenium in feed did not influence portions of myristic, eicosenoic, $\gamma$-linoleic and eicosapentaenoic fatty acid in breast muscle lipids $(P=0.361)$.

However, the amount of selenium in feed, which was increased from $0.0822 \mathrm{mg} / \mathrm{kg}$ in group P1 to $0.2840 \mathrm{mg} / \mathrm{kg}$ in group P2, had a significant effect on the increase of the following fatty acids in broiler muscle tissue: pentadecanoic, heptadecanoic, stearic, arachidic, behenic, lignoceric, linoleic, eicosadienoic, dihomo- $\gamma$-linoleic, arachidic, $\alpha$-linolenic fatty acid, eicosatrienoic, dochosapentaenoic and dochosahexaenoic fatty acid. When the content of selenium in feed was increased to $0.4380 \mathrm{mg} / \mathrm{kg}$ in group P3, portions of stated fatty acids were lowered to values similar to ones determined for broiler group that had diets with no supplemented selenium $(P<0.05)$. In contrast, portions of palmitic, myristoleic, palmitoleic and oleic fatty acids were considerably increased in group P2, while in group P3 their content was similar as in group P1 $(P<0.05)$. A portion of saturated fatty acids was similar in groups P1 and P3 $(29.22 \%$ and $29.53 \%$, respectively); in group P2 it was $28.58 \%$. The amount of selenium supplemented to feed did not have an effect on the determined differences in portions of total saturated fatty acids in breast muscle $(P=0.256)$. Significantly smaller portion of total monounsaturated fatty acids was determined in group P2 (27.26\%) compared to groups P1 and P3 $32.74 \%$ and $32.46 \%$, respectively), whereas a portion of total $n-6$ polyunsaturated fatty acids and n-3 polyunsaturated fatty acids was significantly higher $(P<0.001)$ in group P2 $(33.82 \%$ and $8.72 \%$, respectively) compared to group P1 (30.21\% and $6.78 \%$, respectively) and group P3 (30.27\% and $6.71 \%$, respectively). Ratio of $n-6$ polyunsaturated fatty acids and n-3 polyunsaturated fatty acids corresponded to values of total $n-6$ polyunsaturated fatty acids and n-3 polyunsaturated fatty acids. The closest n-6/n-3 polyunsaturated fatty acids ratio was determined in group P2 $(3.87: 1)$, being significantly $(P<0.001)$ different from ratios obtained in groups $\mathrm{P} 1$ and $\mathrm{P} 3$ (4.46:1 and 4.50:1, respectively). The increase of selenium content in feed from $0.0 \mathrm{mg} / \mathrm{kg}$ to $0.3 \mathrm{mg} / \mathrm{kg}$ affected the fatty acid profile in breast muscle tissue, increased portion of $\alpha$-linolenic fatty acids, eicosapentaenoic fatty acids, docosapentaenoic fatty acids, docosahexaenoic fatty acids and total n3 polyunsaturated fatty acids, and decreased portion of total saturated fatty acids and monounsaturated fatty acids. 
Table 1 . Fatty acid content in broiler breast muscle

\begin{tabular}{|c|c|c|c|}
\hline Fatty acid & $\begin{array}{l}\mathrm{P} 1 * \\
\bar{x} \pm \mathrm{s}\end{array}$ & $\begin{array}{c}\mathrm{P} 2 \\
\bar{x} \pm \mathrm{s}\end{array}$ & $\begin{array}{c}\mathrm{P} 3 \\
\bar{x} \pm \mathrm{s}\end{array}$ \\
\hline Myristic (C14:0) & $0.39 \pm 0.01$ & $0.40 \pm 0.03$ & $0.41 \pm 0.04$ \\
\hline Pentadecanoic (C15:0) & $0.08 \pm 0.01^{\mathrm{b}}$ & $0.09 \pm 0.01^{\mathrm{a}}$ & $0.08 \pm 0.01^{\mathrm{b}}$ \\
\hline Palmitic (C16:0) & $20.98 \pm 0.24^{\mathrm{a}}$ & $19.12 \pm 1.22^{b}$ & $21.29 \pm 0.99^{\mathrm{a}}$ \\
\hline Heptadecanoic (C17:0) & $0.12 \pm 0.02^{\mathrm{b}}$ & $0.15 \pm 0.02^{\mathrm{a}}$ & $0.10 \pm 0.00^{\mathrm{b}}$ \\
\hline Stearic (C18:0) & $7.44 \pm 0.26^{\mathrm{b}}$ & $8.51 \pm 0.98^{\mathrm{a}}$ & $7.42 \pm 0.26^{\mathrm{b}}$ \\
\hline Arachidic (C20:0) & $0.09 \pm 0.00^{\mathrm{b}}$ & $0.13 \pm 0.01^{\mathrm{a}}$ & $0.10 \pm 0.01^{\mathrm{b}}$ \\
\hline Behenic (C22:0) & $0.06 \pm 0.00^{\mathrm{b}}$ & $0.09 \pm 0.02^{\mathrm{a}}$ & $0.07 \pm 0.01^{\mathrm{b}}$ \\
\hline Lignoceric (C24:0) & $0.05 \pm 0.01^{\mathrm{b}}$ & $0.08 \pm 0.01^{\mathrm{a}}$ & $0.05 \pm 0.01^{\mathrm{b}}$ \\
\hline$\sum$ Saturated & $29.22 \pm 0.34$ & $28.58 \pm 1.65$ & $29.53 \pm 0.73$ \\
\hline Myristoleic (C14:1) & $0.08 \pm 0.01^{\mathrm{a}}$ & $0.05 \pm 0.02^{\mathrm{b}}$ & $0.08 \pm 0.02^{\mathrm{a}}$ \\
\hline Palmitoleic (C16:1) & $3.28 \pm 0.46^{\mathrm{a}}$ & $1.94 \pm 0.71^{\mathrm{b}}$ & $3.19 \pm 2.77^{\mathrm{a}}$ \\
\hline Oleic (C18:1n9) & $29.02 \pm 0.68^{\mathrm{a}}$ & $25.23 \pm 2.34^{b}$ & $28.71 \pm 1.33^{\mathrm{a}}$ \\
\hline Eicosenoic (C20:1) & $0.26 \pm 0.02$ & $0.25 \pm 0.02$ & $0.25 \pm 0.02$ \\
\hline Nervonic (C24:1) & $0.10 \pm 0.04^{\mathrm{b}}$ & $0.23 \pm 0.06^{\mathrm{a}}$ & $0.22 \pm 0.02^{\mathrm{a}}$ \\
\hline$\sum$ Monounsaturated & $32.74 \pm 0.75^{\mathrm{a}}$ & $27.26 \pm 2.96^{\mathrm{b}}$ & $32.46 \pm 2.05^{\mathrm{a}}$ \\
\hline Linoleic (C18:2n6) & $26.61 \pm 1.04^{\mathrm{b}}$ & $29.19 \pm 1.68^{\mathrm{a}}$ & $26.87 \pm 2.05^{b}$ \\
\hline$\gamma$-linoleic (C18:3n6) & $0.15 \pm 0.03$ & $0.14 \pm 0.01$ & $0.15 \pm 0.01$ \\
\hline Eicosadienoic (C20:2n6) & $0.49 \pm 0.08^{b}$ & $0.72 \pm 0.18^{\mathrm{a}}$ & $0.52 \pm 0.09^{b}$ \\
\hline Dihomo- $\gamma$-linoleic (C20:3n6) & $0.64 \pm 0.14^{\mathrm{ab}}$ & $0.75 \pm 0.15^{\mathrm{a}}$ & $0.56 \pm 0.01^{\mathrm{b}}$ \\
\hline Arachidonic (C20:4n6) & $2.33 \pm 0.32^{\mathrm{b}}$ & $3.01 \pm 0.65^{\mathrm{a}}$ & $2.16 \pm 0.18^{\mathrm{b}}$ \\
\hline En-6 Polyunsaturated & $30.21 \pm 0.99^{\mathrm{b}}$ & $33.82 \pm 1.65^{\mathrm{a}}$ & $30.27 \pm 2.24^{b}$ \\
\hline$\alpha$-linolenic (C18:3n3) & $5.14 \pm 0.32^{\mathrm{b}}$ & $6.29 \pm 0.38^{\mathrm{a}}$ & $4.39 \pm 0.18^{b}$ \\
\hline Eicosatrienoic (C20:3n3) & $0.19 \pm 0.04^{\mathrm{b}}$ & $0.28 \pm 0.08^{\mathrm{a}}$ & $0.19 \pm 0.02^{\mathrm{b}}$ \\
\hline Eicosapentaenoic (C20:5n3) & $0.29 \pm 0.04$ & $0.34 \pm 0.09$ & $0.29 \pm 0.02$ \\
\hline Docosapentaenoic (C22:5n3) & $0.76 \pm 0.11^{\mathrm{b}}$ & $1.21 \pm 0.25^{\mathrm{a}}$ & $0.79 \pm 0.03^{\mathrm{b}}$ \\
\hline Docosahexaenoic (C22:6n3) & $0.39 \pm 0.04^{\mathrm{b}}$ & $0.59 \pm 0.19^{\mathrm{a}}$ & $0.50 \pm 0.05^{\mathrm{ab}}$ \\
\hline En-3 Polyunsaturated & $6.78 \pm 0.16^{\mathrm{b}}$ & $8.72 \pm 0.70^{\mathrm{a}}$ & $6.71 \pm 0.24^{\mathrm{b}}$ \\
\hline n-6/n-3 Polyunsaturated & $4.46 \pm 0.04^{\mathrm{a}}$ & $3.87 \pm 0.18^{\mathrm{b}}$ & $4.50 \pm 0.19^{\mathrm{a}}$ \\
\hline Other & $1.04 \pm 0.25$ & $1.18 \pm 0.24$ & $1.03 \pm 0.08$ \\
\hline
\end{tabular}

*P1 - group of broilers fed with no selenium supplement; group P2 - feed supplemented with $0.3 \mathrm{mg} \mathrm{Se} / \mathrm{kg}$ of feed; group P3 - feed supplemented with $0.5 \mathrm{mg} \mathrm{Se} / \mathrm{kg}$ of feed; $\bar{x}$ - mean; s-standard deviation; ${ }^{\mathrm{a}, \mathrm{b}}$ statistical differences between groups $(P<0.05)$

Table 2. Effect of selenium on lipid oxidation in broiler breast muscles

\begin{tabular}{|c|c|c|}
\hline \multicolumn{3}{|c|}{ TBARS values (nmol MDA/g tissue) } \\
\hline Experimental groups & Fresh tissue & Tissue stored for 28 days \\
\hline & $\bar{x} \pm \mathrm{s}$ & $\bar{x} \pm \mathrm{s}$ \\
\hline$\overline{\mathrm{P} 1}$ & $3.97 \pm 1.77$ & $5.50 \pm 4.37$ \\
\hline $\mathrm{P} 2$ & $3.56 \pm 1.97$ & $5.44 \pm 0.71$ \\
\hline P3 & $3.44 \pm 2.04$ & $4.94 \pm 2.58$ \\
\hline
\end{tabular}

TBARS - Thiobarbituric Acid Reactive Substances; MDA - malonaldehyde; group P1 - broiler fed with no selenium supplement; group P2 - feed supplemented with $0.3 \mathrm{mg} \mathrm{Se} / \mathrm{kg}$ of feed; P3 - feed supplemented with $0.5 \mathrm{mg}$ $\mathrm{Se} / \mathrm{kg}$ of feed; $\bar{x}$ - mean; s -standard deviation.

Increased content of selenium in broiler feed did not affect the lipid oxidation intensity in breast muscles $(P>0.05)$. However, it is important to point out that the increased content of selenium in broiler feed decreased TBARS values in fresh breast muscle tissue 
(3.97 nmol MDA/g tissue, $3.56 \mathrm{nmol} \mathrm{MDA} / \mathrm{g}$ tissue and $3.44 \mathrm{nmol} \mathrm{MDA} / \mathrm{g}$ tissue in P1, P2 and $\mathrm{P} 3$ groups, respectively), as well as in 28 -day old tissue kept at $-20^{\circ} \mathrm{C}(5.50 \mathrm{nmol} \mathrm{MDA} / \mathrm{g}$ tissue, $5.44 \mathrm{nmol} \mathrm{MDA} / \mathrm{g}$ tissue and $4.94 \mathrm{nmol} \mathrm{MDA} / \mathrm{g}$ tissue in groups P1, P2 and P3, respectively).

\section{Discussion}

Marković et al. (2010) studied the use of organic selenium in production of functional food and determined that the content of selenium in breast muscles increased in proportion to its increased amounts added to broiler feed. Their results are in accordance with our results. Ševčíková et al. (2006) pointed out that the increase of selenium in broiler feed from $0.0 \mathrm{mg} / \mathrm{kg}$ to $0.3 \mathrm{mg} / \mathrm{kg}$ significantly $(P<0.05)$ affected the amount of selenium contained in breast meat by increasing it from $52.11 \mu \mathrm{g} / \mathrm{kg}$ to $217.39 \mu \mathrm{g} / \mathrm{kg}$ of tissue. Our results correspond to the results of these authors. Haug et al. (2007) determined a significant effect of selenium contained in broiler feed on the content of eicosapentaenoic, docosapentaenoic and docosahexaenoic in thigh muscles, i.e. increased content of selenium in feed affected the increase of fatty acid content in thigh muscles $(P<0.05)$. Our study showed a trend of increase in the content of eicosapentaenoic and docosapentaenoic fatty acids in breast muscle tissue, while Haug et al. (2007) reported the same increase in thigh muscle tissue. These authors explained that higher content of selenium in feed affected the activity of $\Delta^{6}-, \Delta^{5}$ - and $\Delta^{4}$ - desaturase and elongase, which catalyze elongation and desaturation of short-chain fatty acids into long-chain fatty acids, or that intake led to reduced speed of long-chain fatty acids degradation in peroxidation processes. In our study, we noticed that the amount of $0.5 \mathrm{mg} \mathrm{Se} / \mathrm{kg}$ of feed influenced portions of $\mathrm{n}-3$ PUFA to equalize with values determined for group P1, which was fed diets with no added selenium. It was assumed that redundancy of selenium in feed for group P3 was necessary for saturation of some antioxidative selenoenzymes in cells, because it was noticed that the lipid oxidation value in that group was the lowest. Dlouhá et al. (2008) stated that organic selenium in broiler feed influenced lower lipid oxidation of both fresh and stored breast muscle tissue. These results were in accordance with results obtained in our study. Wang et al. (2009) pointed out that selenium in feed (no selenium i.e. $0.6 \mathrm{mg} / \mathrm{kg}$ ) had a significant $(P<0.001)$ effect on the lowering of lipid oxidation in breast muscle tissue (from $0.34 \mathrm{mg}$ / $\mathrm{kg}$ MDA to $0.30 \mathrm{mg} / \mathrm{kg}$ MDA, respectively). These results corresponded to results obtained in our study, considering the trends of breast muscle TBARS values, which were lowered in proportion to the increase of selenium content in feed.

Use of plant oils in broiler feed production and supplementation of organic selenium to feed at the amount of $0.3 \mathrm{mg} / \mathrm{kg}$ and $0.5 \mathrm{mg} / \mathrm{kg}$ of feed will result in production of broiler white meat enriched with selenium $(0.183 \mathrm{mg} / \mathrm{kg}$ and $0.256 \mathrm{mg} / \mathrm{kg}$, respectively) and with n-3 polyunsaturated fatty acids (8.72\% and $6.71 \%$, respectively). Such product can be labelled as functional food. The research resulted in the conclusion that increase of selenium content in the feed affected the increase of $n-3$ polyunsaturated fatty acids in broiler breast muscle. A portion of total n-3 polyunsaturated fatty acids in feed containing $0.3 \mathrm{mg} \mathrm{Se} / \mathrm{kg}$ feed exhibited a growing trend, and further increase of selenium content in feed $(0.5 \mathrm{mg} \mathrm{Se} / \mathrm{kg}$ feed) resulted in their declining trend.

\section{References}

Csapó J, Sugár L, Horn A, Csapó JNE. 1986: Chemical composition of milk from red deer, roe and fallow deer kept in captivity. Acta Agron Hung 3-4: 359-372

Davidowski L 1993: PerkinElmer ICP Application Study Number 67

Dlouhá G, Ševčíková S, Dokoupilová A, Zita L, Heindl J, Skřivan M: 2008: Effect of dietary selenium sources on growth performance, breast muscle selenium, glutathione peroxidase activity and oxidative stability in broilers. Czech J Anim Sci 53: 265-269 
Haug A, Eich-Greatorex S, Bernhoft A, Wold JP, Hetland H, Christophersen OA, Sogn T 2007: Effect of dietary selenium and omega-3 fatty acids on muscle composition and quality in broilers. Lipids Health Dis 6: 29

Marković R, Baltić Z, Petrujkić B, Radulović S, Krstić M, Šefer D, Šperanda M 2010: Use of organic selenium in broiler nutrition. Krmiva 51: 287-295

Ohkawa H, Ohishi N, Yagi K 1979: Assay for lipid peroxides in animal tissues by thiobarbituric acid reaction. Anal Biochem 95: 351-358

Ševčíková S, Skřivan M, Dlouhá G, Koucký M 2006: The effect of selenium source on the performance and meat quality of broiler chickens. Czech J Anim Sci 51: 449-457

Statistica for Windows v. 7.0 (Statsoft Inc., 2004)

Wang ZG, Pan XJ, Peng ZQ, Zhao RQ, Zhou GH 2009: Methionine and selenium yeast supplementation of the maternal diets affects color, water-holding capacity, and oxidative stability of their male offspring meat at the early stage. Poult Sci 88: 1096-1101 